\title{
RESILIENSI NAFKAH RUMAHTANGGA PETANI HUTAN RAKYAT DI KECAMATAN GIRIWOYO, WONOGIRI
}

\author{
The Livelihood Resilience of Forest Community Farmer Household in Giriwoyo, Wonogiri
}

\author{
Yudhistira Saraswati*) dan Arya Hadi Dharmawan \\ Departemen Sains Komunikasi dan Pengembangan Masyarakat, Fakultas Ekologis Manusia, IPB \\ *)Email : tirayudhistira@gmail.com
}

\begin{abstract}
Community forest is forest management that not only considering the aspect of ecology but also economic aspect, likely increasing income, and improving the welfare of farmers. Community forest famer household not only use natural capital in livelihood activities, but also used other livelihood asset that can be used to produce income. The method used is a combination of quantitative approach by asking questionnaires and qualitative with in-depth interviews. The purpose of this research is knowing resilience built the household form livelihood asset. Resilience defined as ability individual or group to survive of shocks and crisis. The result showed that resilience affected by ownership of livelihood asset and household incomes. Livelihood assets used by household to livelihood strategy, untill can building livelihood resilience's household.
\end{abstract}

Keywords : community forest, livelihood asset, livelihood strategy, resilience.

\begin{abstract}
ABSTRAK
Hutan rakyat merupakan pengelolaan hutan yang tidak hanya mempertimbangkan aspek ekologi tetapi juga aspek ekonomi, hutan rakyat sangat memungkinkan untuk dapat meningkatkan pendapatan dan mengembangkan kesejahteraan petani. Rumah tangga petani hutan rakyat tidak hanya memanfaatkan modal alam dalam aktivitas penghidupan, tetapi juga menggunakan modal yang dapat digunakan untuk menghasilkan pendapatan. Metode yang digunakan yakni kombinasi dari pendekatan kuantitatif dengan menggunakan kuesioner dan pendekatan kualitatif dengan wawancara mendalam. Tujuan dari penelitian ini yaitu untuk mengetahui bentuk resiliensi yang diterapkan rumahtangga untuk membentuk modal (livelihood asset). Resiliensi diartikan sebagai kemampuan individu atau kelompok untuk bertahan menghadapi guncangan atau krisis. Hasil dari penelitian ini adalah resiliensi dipengaruhi oleh kepemilikan modal dan pendapatan rumahtangga. Modal rumahtangga digunakan oleh rumahtangga petani sebagai strategi nafkah, hingga dapat membangun resiliensi rumahtangga.
\end{abstract}

Kata kunci : hutan rakyat, modal, resiliensi, strategi rumah tangga

\section{PENDAHULUAN}

\section{Latar Belakang}

Indonesia dikenal sebagai negara dengan kekayaan alam yang sangat melimpah dan beragam. Di sektor kehutanan khususnya, Indonesia memiliki kawasan hutan seluas \pm 130 juta hektar. Salim (2004) menyatakan bahwa hutan di Indonesia merupakan harta kekayaan yang tidak ternilai, maka dari itu hak-hak negara atas hutan dan hasilnya perlu dijaga, dipertahankan, dan dilindungi agar hutan dapat berfungsi dengan baik. Hutan rakyat menjadi salah satu alternatif pengelolaan hutan.

Wijiadi (2007) menyebutkan bahwa jika dilihat dari fungsi dibangunnya, hutan rakyat merupakan bentuk pengelolaan lahan yang mempertimbangkan aspek kelestarian hasil dan aspek konservasi namun tetap memberikan peluang untuk meningkatkan hasil tanaman pangan, peningkatan pendapatan, dan perbaikan kesejahteraan petani. Hal tersebut searah dengan Peraturan Menteri Nomor 1 Tahun
2004 yang mengeluarkan lima kebijakan prioritas, dimana salah satunya berkaitan dengan pelestarian hutan rakyat yaitu "menjadikan proyek-proyek hutan rakyat sebagai kebijakan untuk memberdayakan ekonomi masyarakat yang tinggal di dalam dan sekitar hutan".

Pengelolaan hutan rakyat pada dasarnya bertujuan untuk melestarikan sumber daya hutan agar tetap terjamin kesinambungan persediaannya di masa yang akan datang (Marwoto, 2012). Hutan rakyat di Jawa umumnya digunakan oleh masyarakat sekitar untuk menanam pohon yang menghasilkan kayu untuk diinvestasikan atau dijual seperti jati, mahoni, dan sengon yang bernilai ekonomis tinggi. Tanaman lain non-kayu yang dapat dimanfaatkan sebagai bahan pangan (palawija, buah-buahan, dan sayursayuran) atau komoditas seperti tanaman apotik hidup. Selain itu hasil hutan dapat berupa karbon dan bermanfaat secara ekologi. Hal ini menjadikan hutan sebagai sumber penghidupan masyarakat yang harus dilestarikan. Masyarakat sekitar hutan menggantungkan hidupnya di hutan sebagai cara bertahan hidup. 
Strategi nafkah menurut Yuliandani (2011) didefinisikan sebagai cara dimana orang memenuhi kebutuhan mereka atau peningkatan hidup, namun lebih mendalam seperti yang diutarakan oleh Dharmawan (2007) strategi nafkah bukan sekedar means of living yang bermakna sebagai mata pencaharian. Pengertian strategi nafkah lebih mengacu pada pengertian livelihood strategy (strategi penghidupan) yaitu strategi membangun sistem penghidupan, cara bertahan hidup atau memperbaiki status kehidupan. Strategi nafkah akan dilakukan oleh seseorang sepanjang mereka hidup. Pada saat seseorang atau suatu rumahtangga mengalami krisis atau guncangan posisi mereka akan mengalami kegoyahan, dalam hal ini mereka akan berusaha untuk bertahan dan mengembalikan ke posisi semula. Kemampuan tersebut yang selanjutnya akan disebut dengan kelentingan atau resiliensi nafkah. Strategi nafkah yang diterapkan oleh rumahtangga akan berbeda pada saat kondisi normal dan kondisi krisis. Kondisi krisis akan memaksa untuk berbuat lebih agar bisa menghadapi krisis tersebut.

Hutan sebagai salah satu sumber penghidupan masyarakat memiliki peranan penting dalam menjamin kelangsungan hidup manusia. Kabupaten Wonogiri merupakan salah satu wilayah yang berada di Provinsi Jawa Tengah dengan luas wilayah hutan rakyat seluas 39.453 hektar pada akhir 2012. Hutan menjadi salah satu prioritas utama pengembangan karena berhubungan dengan kelestarian fungsi dan optimalisasi manfaat Waduk Gajah Mungkur. Di samping itu, hutan rakyat di Wonogiri telah memberikan manfaat ekonomis yaitu sebagai sumber mata pencaharian masyarakat sekitar. Hal tersebut juga dipaparkan oleh Wardhana (2008) bahwa penerapan hutan rakyat dan pengelolaan kepada masyarakat juga mampu mendorong suatu perubahan tingkat sosial yang cukup besar di sekitar daerah atau areal hutan tersebut. Hutan rakyat menjadikan masyarakat dapat merasakan manfaatnya, di antaranya tersedianya peluang kerja yang cukup besar sehingga masyarakat dapat terlibat terutama pada saat adanya pemanenan kayu.

Kecamatan Giriwoyo, Kabupaten Wonogiri merupakan wilayah yang memiliki kawasan hutan rakyat seluas 4.968 hektar. Kondisi sosial di kecamatan ini memperlihatkan bahwa mayoritas penduduk menggantungkan hidupnya dari pengolahan lahan baik sebagai petani maupun buruh tani. Kegiatan pertanian dilakukan pada sawah basah, lahan kering atau keduanya. Pada petani lahan basah sangat rawan mengalami gagal panen karena daerah ini merupakan daerah rawan kekeringan. Maka dari itu, banyak masyarakat di sana yang bertani pada lahan kering atau petani hutan. Lahan-lahan petani sekarang banyak ditanami dengan tanaman kayu seperti jati, mahoni, akasia, sonokeling, dan jambu mete. Secara tidak langsung penanaman tanaman berkayu ini sangat membantu dalam melindungi tanah dari bahaya longsor karena kayu memiliki sistem perakaran yang kuat (Marwoto, 2012).

Daerah Kecamatan Giriwoyo merupakan daerah yang dulunya sering mengalami kekeringan. Kekeringan yang melanda daerah ini dikarenakan keadaan topologinya yang berada pada posisi yang curam dengan kemiringan lahan berkisar antara $15 \%$ sampai $40 \%$. Kondisi ini kurang cocok untuk usaha pertanian seperti sawah (pertanian basah), selain itu kegiatan untuk pertanian kurang mendukung karena tanahnya yang berbatu dan kering. Hal tersebut mengakibatkan produksi tamanan khususnya padi sawah kurang maksimal. Para petani melakukan usaha tani di tegalan dengan tanaman palawija seperti jagung, kedelai, dan kacang kadang juga harus menghadapi banyaknya hama seperti kera dan celeng yang memakan tanaman mereka.

Banyak kendala yang dihadapi oleh masyarakat untuk menghadapi hidup, selain karena faktor alam seperti bencana alam dan kondisi alam yang tidak mendukung terdapat juga faktor lain seperti guncangan ekonomi seperti kebutuhan hidup yang semakin meningkat dan kebutuhan mendesak rumahtangga. Mereka harus mempunyai resiliensi untuk tetap dapat bertahan hidup. Resiliensi dipandang sebagai kemampuan rumahtangga untuk bertahan dan menstabilkan posisinya dari guncangan dan krisis. Berdasarkan pemaparan tersebut maka fokus penelitian ini adalah bagaimana resiliensi nafkah rumahtangga petani hutan rakyat di Kecamatan Giriwoyo. Kajian ini meliputi identifikasi apa saja modal yang dimiliki oleh rumahtangga, bagaimana strategi dan struktur nafkah rumahtangga petani hutan rakyat.

\section{Masalah Penelitian}

Masalah penelitian dalam kajian ini adalah:

1. Apa saja modal nafkah yang dimiliki rumahtangga petani hutan rakyat?

2. Bagaimana strategi nafkah yang dibangun oleh rumahtangga petani hutan rakyat?

3. Bagaimana struktur nafkah rumahtangga petani hutan rakyat?

4. Bagaimana resiliensi nafkah rumahtangga petani hutan rakyat?

\section{Tujuan Penelitian}

Penelitian ini bertujuan untuk:

1. Mengidentifikasi modal nafkah yang dimiliki rumahtangga petani hutan rakyat.

2. Mengidentifikasi strategi nafkah yang diterapkan rumahtangga petani hutan rakyat.

3. Menganalisis struktur nafkah rumahtangga petani hutan rakyat.

4. Menganalisis resiliensi rumahtangga petani hutan rakyat.

\section{Kegunaan Penelitian}

Penelitian ini diharapkan dapat memberi kegunaan berbagai pihak, antara lain:

1. Bagi peneliti dan kalangan akademisi, penelitian ini diharapkan dapat memberikan tambahan bagi khasanah keilmuan khususnya yang berkaitan dengan resiliensi, livelihood studies, pedesaan, dan juga bidang kehutanan.

2. Bagi pemerintah dan dinas terkait, penelitian ini dapat digunakan sebagai bahan rujukan untuk merumuskan suatu kebijakan terkait pengelolaan sumber daya hutan, perdagangan kayu rakyat dan pemberdayaan masyarakat yang sesuai dengan kondisi masyarakat. 
3. Bagi masyarakat umum, penelitian ini diharapkan mampu menambah wawasan masyarakat mengenai kehidupan masyarakat pedesaan, strategi nafkah, dan resiliensi.

\section{PENDEKATAN TEORITIS}

\section{Tinjauan Pustaka}

\section{Hutan rakyat}

Pendefinisian tentang hutan rakyat sangat beragam karena dapat ditinjau dari beberapa aspek. Menurut UndangUndang Republik Indonesia Nomor 5 Tahun 1967, hutan rakyat diklasifikasikan berdasarkan kepemilikannya yaitu hutan yang tumbuh atau ditanam di atas tanah milik dan dapat dimiliki oleh orang, baik sendiri maupun bersama-sama orang lain atau badan hukum. Wijiadi (2007) menyebutkan bahwa jika dilihat dari fungsi dibangunnya, hutan rakyat merupakan bentuk pengelolaan lahan yang mempertimbangkan aspek kelestarian hasil dan aspek konservasi namun tetap memberikan peluang untuk meningkatkan hasil tanaman pangan, peningkatan pendapatan, dan perbaikan kesejahteraan petani.

Pengelolaan hutan rakyat merupakan upaya menyeluruh dari kegiatan-kegiatan merumuskan, membina, mengembangkan, menilai serta mengawasi pelaksanaan kegiatan produksi, pengolahan hasil dan pemasaran secara berencana dan berkesinambungan. Pola penanaman di hutan rakyat menurut Yumi (2011) dapat digolongkan menjadi tiga kelompok yaitu:

1. Hutan rakyat monokultur atau sebagian besar didominasi satu jenis tanaman keras saja.

2. Hutan rakyat campuran yang memiliki 3-5 jenis tanaman keras. Menurut Suharjito dalam Marwoto (2012) pola hutan rakyat campuran ini masih dibagi menjadi menjadi:

3. Hutan rakyat campuran (polyculture) dengan 2-5 jenis tanaman hutan yang dikembangkan dan diusahakan.

4. Hutan rakyat campuran dengan sistem agroforestry/ wanatani. Pola ini merupakan kombinasi usaha tanaman kehutanan dengan cabang usaha lainnya, seperti perkebunan, pertanian, dan peternakan secara terpadu.

Aryadi (2012) menyatakan bahwa pemanfaatan dan pengelolaan hutan bukan semata-mata merupakan persoalan teknis, tetapi lebih menjadi persoalan sosial yang berpangkal dari pemenuhan kebutuhan dasar dan peningkatan kesejahteraan. Interpretasi masyarakat terhadap program hutan rakyat digolongkan ke tiga aspek:

a. Sosial ekonomi: penambahan penghasilan, memeperluas lapangan kerja, meningkatkan produksi atau hasil sadapan, memberikan harapan atau prospek ke depan, menciptakan lapangan kerja di desa, menyediakan kayu bangunan rumah dan dijual.

b. Sosial budaya: meningkatkan kerjasama, meningkatkan etos kerja masyarakat, mengenal bibit unggul, pengaturan jarak penanaman, dan pembakaran lahan secara izin, merubah peladang berpindah menjadi menetap, masyarakat mandiri, masyarakat menetap di desa, menguatkan sifat kegotong-royongan, meningkatkan derajat keluarga, membuat desa dan masyarakat tentram.

c. Ekologi: mengurangi ancaman dan serangan hama, mencegah kebakaran hutan dan lahan, memanfaatkan lahan kosong, menghijaukan desa, menyediakan air yang cukup meskipun kemarau, memberi ruang kehidupan bagi makhluk Tuhan lainnya.

\section{Strategi nafkah}

Dharmawan (2007) menyebutkan strategi nafkah bukan sekedar means of living yang bermakna sebagai matapencaharian. Pengertian strategi nafkah lebih mengacu pada pengertian livelihood strategy (strategi penghidupan) yaitu strategi membangun sistem penghidupan, cara bertahan hidup atau memperbaiki status kehidupan. Strategi nafkah suatu rumahtangga menyangkut keberlangsungan hidup anggota rumahtangga tersebut.

Rumahtangga petani menerapkan strategi nafkah yang berbeda-beda seperti pada rumahtangga peserta PHBM di Kabupaten Kuningan yang dijelaskan oleh Purnomo (2006) dimana diklasifikasikan dalam 1). Strategi nafkah basis modal alami terdiri atas: ekstensifikasi, orientasi, investasi, integrasi, dan asuransi. 2). Strategi nafkah basis modal bukan alami terdiri atas: basis remittance, basis modal sosial dan basis pekerjaan dalam desa. Sedangkan Fridayanti (2013) menggolongkan strategi nafkah rumahtangga petani di Desa Cipeuteuy, Kabupaten Sukabumi: 1). Intensifikasi strategi pertanian dengan memanfaatkan sektor pertanian secara efektif dan efisien; 2). Intensifikasi strategi non pertanian memanfaatkan sektor non pertanian dengan lebih efektif dan efisien melalui penerapan beragam pekerjaan di luar sektor pertanian; 3). Diversifikasi nafkah menerapkan keanekaragaman pola nafkah dengan cara mencari pekerjaan lain selain pertanian untuk menambah pendapatan, atau dengan mengerahkan tenaga kerja keluarga; dan 4). Rekayasa spasial (migrasi) usaha mobilitas ke daerah lain di luar desanya, baik secara permanen maupun sirkuler untuk memperoleh pendapatan.

\section{Struktur nafkah}

Prasetya (2013) menyebutkan bahwa struktur nafkah adalah komposisi pendapatan rumahtangga petani dari berbagai aktivitas nafkah yang dilakukan oleh seluruh anggota rumahtangga. Pendapatan tersebut berasal dari:

a. Berasal dari on-farm atau sektor pertanian dalam arti luas (pertanian, perkebunan, kehutanan, peternakan, dll) yang terlibat secara langsung dalam produksi.

b. Berasal dari off-farm masih dalam sektor pertanian namun lebih mengacu berupa upah tenaga kerja pertanian, sistem bagi hasil, dan sebagainya.

c. Berasal dari non-farm yaitu sumber pendapatan yang berasal dari luar kegiatan pertanian.

Dalam melaksanakan strategi nafkah, faktor yang mempengaruhi adalah ketersediaan sumber daya dan kemampuan dalam mengakses sumber daya tersebut. Dharmawan (2001) dalam Turasih (2011), sumber daya nafkah rumahtangga sangat beragam (multiple source of livelihood) karena rumahtangga tidak bisa memenuhi kebutuhannya jika hanya bergantung pada satu pekerjaan dan satu sumber nafkah saja. Terdapat lima bentuk modal 
atau biasa disebut livelihood asset dalam Ellis (2000), yaitu:

a. Modal sumber daya alam (Natural capital): modal yang diperoleh dari alam atau lingkungan baik sumber daya yang dapat diperbaharui ataupun tidak dapat diperbaharui. Contoh: air, tanah, kayu atau sumber daya mineral seperti minyak, emas, dan lain sebagainya.

b. Modal fisik (Physical capital): modal yang dapat diciptakan oleh manusia yang berbentuk infrastruktur. Contoh: sistem irigasi, jalan, dan lain sebagainya.

c. Modal manusia (Human capital): modal yang dimiliki atau ada dalam diri manusia, yaitu tenaga kerja yang tersedia dalam rumahtangga yang dipengaruhi oleh pendidikan, ketrampilan, dan kesehatan.

d. Modal finansial (Financial capital and subtitutes): Modal yang berupa uang yang dapat digunakan untuk modal pencarian nafkah. Contoh: berupa uang tunai, tabungan, ataupun akses dan pinjaman.

e. Modal sosial (Social capital): modal ini berupa kepercayaan (trust), jaringan kerja (networking), oraganisasi dan segala bentuk hubungan untuk bekerja sama serta memberikan bantuan untuk memperluas akses terhadap kegiatan ekonomi.

\section{Resiliensi}

Walker et.al (2004) mendefinisikan resiliensi adalah kemampuan sistem untuk menyerap gangguan dan mereorganisasi saat menjalani perubahan sehingga masih mempertahankan fungsi dasarnya. Resiliensi nafkah dipandang sebagai kemampuan untuk menghadapi guncangan atau krisis ekonomi sehingga masih dapat bertahan hidup, masih dalam posisi yang stabil, tidak mengalami keterpurukan yang berkepanjangan, dan kelaparan. Bentuk dari resiliensi tersebut beragam sesuai dengan sumber daya yang dimiliki. Wulan (2004) dalam penelitiannya menyebutkan bentuk resiliensi nafkah rumahtangga petani di Desa Ciganjeng mencakup aspek saving capacity, ketersediaan kesempatan kerja di luar, kemampuan akses terhadap kesempatan kerja lain, ketersedian modal sosial, ketersediaan teknologi pendukung, natural extraction activities, dan pengurangan jatah makanan.

\section{Kerangka Pemikiran}

Rumahtangga memiliki sumberdaya atau aset yang disebut dengan modal nafkah (X1). Modal nafkah terdiri dari modal manusia, modal fisik, modalalam, modal sosial, dan modal finansial. Modal-modal nafkah tersebut dimainkan sedemikian rupa dalam bentuk strategi nafkah (X2). Strategi nafkah yang dibangun rumahtangga akan mempengaruhi struktur nafkah (X3) rumahtangganya. Struktur nafkah dalam penelitian ini terdiri dari pendapatan farm, pendapatan non-farm, dan pendapatan kayu.

Modal nafkah, strategi nafkah dan struktur nafkah ini yang akan mempengaruhi kemampuan rumahtangga untuk bertahan hidup dari guncangan dan krisis ekonomi atau yang disebut dengan resiliensi (Y). Dalam kajian ini juga akan dilihat bagaimana peranan hutan rakyat dalam menopang resiliensi rumahtangga. Kerangka pemikiran sebagai berikut:

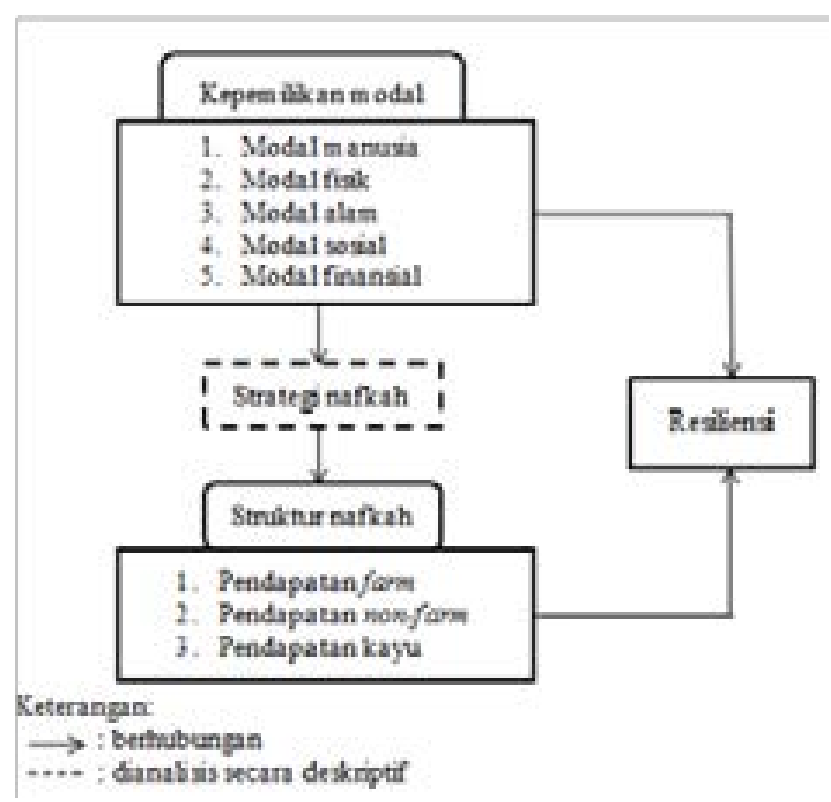

Gambar 1 Kerangka pemikiran

\section{Hipotesis}

1. Terdapat hubungan antara kepemilikan modal dengan strategi nafkah.

2. Terdapat hubungan antara strategi nafkah dengan struktur nafkah.

3. Terdapat hubungan antara tingkat kepemilikan modal dan tingkat pendapatan dengan tingkat resiliensi.

\section{PENDEKATAN LAPANG}

\section{Lokasi dan Waktu Penelitian}

Penelitian ini dilakukan di Desa Sejati dan Desa Selomarto Kecamatan Giriwoyo, Kabupaten Wonogiri, Jawa Tengah. Pemilihan desa lokasi penelitian dilakukan secara sengaja (purposive). Kedua desa dipilih karena rumahtangga di desa tersebut sebagian besar memiliki hutan (lahan) yang ditanami kayu-kayuan dan mengelola hutan tersebut baik secara langsung maupun tidak langsung sehingga dapat masuk dalam pendefinisian rumahtangga petani hutan rakyat. Kegiatan penelitian ini berlangsung dari bulan Februari hingga Juni 2014.

\section{Teknik Penentuan Responden dan Informan}

Responden adalah rumahtangga petani hutan rakyat. Rumahtangga petani hutan rakyat yang dimaksud adalah rumahtangga yang memiliki kayu baik di tegalan, pekarangan maupun sawah yang dikelola secara rutin atau hanya musiman. Penentuan responden dilakukan secara stratified sampling yang diklasifikasikan menurut luas penguasaan lahan. Jumlah responden setiap desa responden sebanyak 30 responden.

Informan dalam penelitian ini adalah responden atau instansi yang mengetahui informasi tambahan atau pendukung yang terkait topik penelitian. Informan yang dimaksud adalah tokoh masyarakat dan dari pihak pemerintah (kecamatan 
dan desa). Pemilihan informan dilakukan dengan teknik penarikan bola salju (snowball), yaitu memilih informan berdasarkan informasi dari informan sebelumnya.

\section{Teknik Pengumpulan Data}

Data primer diperoleh dengan mengumpulkan data kuantitatif dari kuesioner. Data kualitatif diperoleh dari responden dan informan yang diperoleh melalui pengamatan, observasi dan wawancara mendalam. Hasil dari pengamatan dan wawancara dituangkan dalam catatan harian dengan bentuk uraian rinci dan kutipan langsung. Data sekunder diperoleh dari informasi tertulis, data-data dan literatur-literatur yang mendukung kebutuhan data. Data-data diperoleh dari pemerintahan desa, kecamatan, dinas terkait, kelompok petani, dan penelusuran informasi melalui pustaka.

\section{Teknik Pengolahan dan Analisis Data}

Data kuantitatif diolah dengan tabulasi silang dan tabel frekuensi kemudian dianalisis secara deskriptif. Uji hubungan dilakukan dengan Rank Sperman dengan software SPSS versi 22. Uji kolerasi menyatakan hubungan jika nilai Sig $(p<0,01)$. Pengolah pendapatan rumahtangga dilakukan dengan membuat kurva sebaran normal.

Data kualitatif disajikan secara deskriptif untuk menjelaskan dan memperkuat analisis dari data kuantitatif yang diperoleh. Data yang diperoleh dalam penelitian baik data kuantitatif dan data kualitatif digabungkan dan disajikan dalam bentuk tabel, matriks, dan gambar serta teks naratif. Hasil tersebut kemudian ditarik kesimpulan yang mengacu untuk menjawab pertanyaan-pertanyaan penelitian.

Data kualitatif diolah melalui tiga tahap analisis data kualitatif, yaitu reduksi data, penyajian data, dan penarikan kesimpulan. Reduksi data dilakukan dengan tujuan untuk menajamkan, menggolongkan, mengarahkan, mengeliminasi data-data yang tidak diperlukan sehingga dapat langsung menjawab perumusan masalah.

\section{GAMBARAN UMUM LOKASI PENELITIAN}

\section{Profil Sosio Demografi Lokasi Penelitian}

Kecamatan Giriwoyo merupakan kecamatan yang berada di Kabupaten Wonogiri, Provinsi Jawa Tengah. Secara geografis Kecamatan Giriwoyo terletak pada garis lintang 70 32' sampai 80 15' dan garis bujur 1100 41' sampai 1110 18'. Iklim adalah iklim tropis dengan musim hujan dan kemarau. Suhu udara berkisar pada suhu $330 \mathrm{C}$. Kemiringan tanah berkisar antara $15 \%$ hingga $40 \%$. Kondisi tersebut kurang cocok untuk usaha tani sawah dan pengolahan lahan karena tanahnya yang berbatu dan kering. Luas wilayah Kecamatan Giriwoyo adalah 10.060 hektar.

Karakteristik di Desa Sejati dan Desa Selomarto secaara umum hampir sama baik dari segi ekonomi, sosial, dan fisik. Mayoritas penduduk bermatapencaharian sebagai petani baik petani pemilik atau penggarap (17,3\%). Petani di kedua desa membudidayakan padi dan tanaman palawija. Komoditas yang menjadi khas dari kedua desa ini adalah kayu-kayuan mengingat wilayah Kecamatan Giriwoyo pada umunya berupa tegalan. Pertanian di Desa Sejati dapat dikatakan lebih maju karenakan jenis sawahnya adalah irigasi, sedangkan di Desa Selomarto didominasi sawah tadah hujan. Petani hanya dapat menanam padi setahun satu atau dua kali tergantung hujan datang. Sisanya mereka menanam palawija seperti jagung, kedelai, dan kacang. Berbeda dengan Desa Selomarto, di Desa Sejati petani dapat menanam padi hingga tiga.

Tingkat pendidikan di kedua desa mayoritas adalah tamatan SD Hal ini dikarenakan keterbatasan ekonomi orangtua untuk menyekolahkan anaknya. Minimnya fasilitas pendidikan uga menjadi faktor pendorog lainnya. Mayoritas penduduk kedua desa sebagian besar tamatan $\mathrm{SMP} /$ sederajat. Para kaum muda khususnya setelah menempuh pendidikan pada jenjang SMP atau SMA mereka memutuskan untuk pergi ke kota untuk mencari pekerjaan sebagai buruh bangunan atau buruh industri. Para pekerja migran ini secara rutin atau kadang-kadang mengirimkan sebagian pendapatan ke desa untuk memenuhi kebutuhan sehari-hari.

\section{Hutan Rakyat Di Kecamatan Giriwoyo}

Prioritas dan fokus utama pembangunan bidang kehutanan di Kabupaten Wonogiri diarahkan pada upaya pelestarian Waduk Gajah Mungkur sebagai cathment area (daerah tangkapan air). Waduk Gajah Mungkur telah memberikan manfaat besar bagi masyarakat Wonogiri. Sebagai wujud upaya tersebut banyak program-program untuk pengembangan kawasan hutan yang tercantum dalam Surat Keputusan Bersama Menteri Kehutanan dan Menteri Dalam Negeri Nomor 52 Tahun 1994 dan Nomor 230/ KPTS-II KDH Tingkat.II Wonogiri Nomor 821.2/ 1730/ 1994.

Hutan rakyat di Kecamatan Giriwoyo sendiri diklasifikasikan dalam tiga jenis, yaitu:

a. Hutan rakyat di pekarangan sekitar rumah yang ditanami kayu-kayuan. Pekarangan juga banyak ditanami tanamam pangan, tanaman obat/empon-empon, buahbuahan dan digunakan untuk kandang ternak.

b. Hutan rakyat di sawah. Sawah merupakan lahan yang digunakan menanam tanaman pangan. Hal menarik pada sawah di tempat penelitian adalah adanya tanaman kayu-kayuan. Biasanya tananam kayu ditanam di pematang sawah, tujuannya selain sebagai batas kepemilikan kayu juga dapat mengurangi erosi tanah. Pola seperti ini disebut dengan pola tumpang sari/ agroforestry.

c. Tegalan. Tegalan merupakan lahan kering yang berada lebih jauh dari tempat tinggal petani dan terletak di bawah atau kawasan gunung (tegal gunung). Tegalan yang jenis tanahnya kering kurang cocok untuk ditanami tanaman pangan karena kemiringannya cukup terjal dan tanahnya didominasi batu-batuan sehingga banyak yang menanami dengan tamanan kayu.

Manfaat yang diperoleh masyarakat dari keberadaan hutan rakyat dapat dilihat dari aspek ekonomi dan ekologi. Hutan rakyat dapat mencegah erosi, banjir hingga kekeringan. Dari segi ekonomi selain pendapatan dari hasil hutan rakyat, hutan rakyat dapat membuka lapangan pekerjaan baru bagi masyarakat. Saat penebangan melibatkan banyak orang dari mulai pengangkutan hingga pemasaraan seperti menjadi buruh penggergajian, pedagang, dan sopir pengangkut. 
Sistem pengelolaan hutan rakyat di kedua desa masih tradisional. Penanaman kayu mulai dari pengadaan benih, penanaman, pemeliharaan, pemanenan, dan pemasaran dilakukan secara sederhana. Orientasi penanaman kayu juga masih pada pemenuhan kebutuhan seperti renovasi rumah dan dijual jika kebutuhan mendadak. Kayu belum dijadikan sebagai komoditi komersil yang dapat menghasilkan pendapatan rutin. Akibatnya walaupun hasil kayu dapat dimanfaatkan pada saat ada kebutuhan mendadak namun hutan belum menjadi sumber utama pendapatan rumahtangga.

\section{HASIL DAN PEMBAHASAN}

\section{Modal Nafkah Rumahtangga Petani Hutan Rakyat}

Dalam usaha melakukan strategi nafkah, suatu rumahtangga harus mempunyai modal nafkah (livelihood asset). Modal nafkah tersebut adalah asset yang digunakan rumahtangga untuk melakukan aktivitas nafkahnya. Modal nafkah yang dimiliki rumahtangga petani hutan rakyat adalah sebagai berikut:

\section{a. Modal Manusia}

Modal manusia terdiri dari kelompok usia responden, banyaknya anggota rumahtangga yang bekerja, tingkat pendidikan, dan keterampilan yang dimiliki. Secara umum tingkat pendidikan responden mayoritas adalah tidak sekolah/ tidak lulus SD/ lulus SD. Usia responden sebagian besar berada pada kelompok usia 46-60 tahun yaitu sebesar $63 \%$. Sisanya adalah kelompok usia muda (25-45 tahun) dan tua ( $\geq 46$ tahun).

Responden yang memiliki keterampilan selain bertani hanya 4 responden $(7 \%)$. Keterampilan tersebut adalah pengrajin barang meubel, pengrajin hiasan dengan menggunakan limbah kayu, pengrajin kayu arang yang dijadikan industri rumahtangga. Alokasi pekerja dalam rumahtangga menunjukkan bahwa anggota rumahtangga yang bekerja biasanya adalah kepala rumahtangga dan istri. Hal ini dikarenakan anggota lain seperti anak masih sekolah.

\section{b. Modal Fisik}

Modal fisik meliputi luas penguasaan lahan, kepemilikan hewan ternak, kepemilikan hewan bermotor. Lahan yang dikuasai rumahtangga berupa lahan sawah, pekarangan, dan tegal. Luas penguasaan lahan mayoritas adalah sedang $(55 \%)$ dengan luas (0,5-1ha). Sedangkan rumahtangga yang menguasai lahan luas $(>1$ ha) dan sempit $(<0,5$ ha $)$ menunjukkan proposi yang sama. Macam-macam bentuk penguasaan lahan rumahtangga adalah milik sendiri, bagi hasil, sewa, lelang, dan bengkok.

Hewan ternak yang dimiliki rumahtangga adalah sapi atau kambing. Hewan ternak bagi rumahtangga adalah suatu aset yang dapat digunakan jika ada keperluan mendadak seperti tabungan. Tingkat kepemilikan hewan ternak menunjukkan bahwa $80 \%$ rumahtangga memiliki sapi atau kambing.

Kendaraan bermotor yang dimiliki rumahtangga adalah sepeda motor, mobil atau truk. Sebanyak $92 \%$ rumahtangga memiliki kendaraan bermotor, dimana sekitar $60 \%$ memiliki sepeda motor. Sisanya sekitar32\% memiliki sepeda motor dan atau mobil/truk.

\section{c. Modal Alam}

Modal alam terdiri atas kepemilikan kayu dan sumber daya alam lain yaitu sumber mata air. Tingkat kepemilikan kayu manunjukkan mayoritas rumahtangga $(55 \%)$ memiliki kayu dalam jumlah besar yaitu $>50$ batang pohon kayu. Jenis kayu yang dibudidayakan adalah jati, akasia, mahoni, sengon, dan trembesi. Kayu ini juga dianggap oleh rumahtangga sebagai tabungan yang dapat digunakan jika sewaktu-waktu perlu uang yang relatif besar.

\section{d. Modal Sosial}

Modal sosial dapat dilihat dari kepemilikan jaringan, keterlibatan dalam suatu perkumpulan, dan kekuatan hubungan antar sesama anggota masyarakat. Semua responden memiliki hubungan yang baik dengan anggota masyarakat lain. Sesama warga terjalin interaksi yang baik dan saling memberi bantuan. Hal ini menunjukkan gambaran umum kehidupan sosial di pedesaan yang masih sangat baik.

Keterlibatan responden dalam perkumpulan menunjukkan bahwa semua terlibat dalam perkumpulan sosial seperti arisan dan kegiatan sosial di desa lainnya. Kepemilikan jaringan juga menunjukkan hal yang serupa dimana semua rumahtangga memiliki jaringan sosial. Jaringan sosial dapat membantu seperti memberi bantuan finansial, akses terhadap pekerjaan, dan memberi pengetahuan untuk meningkatkan usaha.

\section{e. Modal Finansial}

Modal finansial meliputi akses terhadap pinjaman, kemampuan menabung, dan penerimaan remitan. Akses terhadap pinjaman dilakukan rumahtangga kepada tetangga dan kerabat $(73 \%)$. Jarang rumahtangga yang meminjam uang ke bank (sekitar 27\%). Umumnya mereka meminjam uang atau beras untuk memenuhi kebutuhnan kebutuhan sehari-hari. Tingkat kemampuan menabung rumahtangga bervariasi dimana rumahtangga yang tidak dapat menyisihkan pendapatannya sebanyak $30 \%$, dapat menyisihkan pendapatan namun tidak rutin $16 \%$, dan sisanya dapat menyisihkan pendapatan secara rutin. Tingkat penerimaan remitan juga menunjukkan hal yang sama dimana sebanyak 52\% tidak menerima remitan, $25 \%$ menerima remitan namun tidak rutin, dan $18 \%$ penerima remitan rutin. Remitan sendiri dimanfaatkan untuk memenuhi keperluan sehari-hari atau keperluan mendadak.

\section{Strategi Nafkah Rumahtangga Petani Hutan Rakyat}

Strategi nafkah adalah cara rumahtangga membangun sistem penghidupan, cara bertahan hidup atau memperbaiki status kehidupan. Rumahtangga membangun strategi nafkah dengan memanfaatkan modal nafkah yang dimilikinya. Ellis (2000) menyebutkan bahwa strategi nafkah merupakan serangkaian pilihan sumber nafkah dan aktivitas nafkah yang meliputi beragam tindakan rasional yang diambil rumahtangga untuk mencapai tujuan yang dirumuskan. Tindakan yang dilakukan berkaitan dengan pemanfaatan penggunaan sumber daya atau aset.

Bentuk aktivitas nafkah yang dilakukan rumahtangga terbagi menjadi tiga yaitu aktivitas nafkah di sektor on-farm, off-farm, dan non-farm. Aktivitas on-farm yang dilakukan adalah menanami lahan dengan tanaman pangan, menanami 
tegal dengan kayu-kayuan, memanfaatkan pekarangan, dan mengurus ternak. Aktivitas nafkah di sektor off-farm adalah kegiatan buruh tani, sedangkan aktivitas nafkah pada sektor non pertanian adalah selain aktivitas on-farm dan non-farm yang beragam jenisnya. Aktivitas pada ketiga sektor tersebut dilakukan oleh rumahtangga sehingga dapat membangun sebuah strategi nafkah untuk bertahan hidup. Strategi nafkah rumahtangga diklasifikasikan dalam tujuh strategi sebagai berikut:

Intensifikasi pendapatan pertanian yaitu dengan memanfaatkan sektor pertanian secara efektif dan efisien. Strategi ini dilakukan rumahtangga golongan usia tua. Hal ini dikarenakan usia dan kebutuhan. Rumahtangga usia tua pada umumnya mempunyai kebutuhan yang tidak banyak karena sudah tidak ada lagi tanggungan. Aktivitas nafkah strategi ini meliputi aktivitas di sektor farm yaitu aktivitas yang dilakukan dalam lingkup pertanian secara luas dan aktivitas off-farm yaitu aktivitas yang dilakukan masih dalam sektor pertanian namun lebih mengacu berupa upah tenaga kerja pertanian, sistem bagi hasil, dan sebagainya.

Intensifikasi pendapatan non pertanian yaitu memanfaatkan sektor non pertanian secara efektif dan efisien. Strategi ini dilakukan karena pendapatan pertanian dirasa tidak dapat mencukupi kebutuhan hidup sehingga rumahtangga terdesak untuk keluar dari sektor pertanian. Strategi intensifikasi pendapatan non pertanian rumahtangga $\mathrm{d} i$ kedua desa terdiri atas dua tipe. Tipe pertama adalah rumahtangga yang tidak mempunyai pendapatan dari sektor pertanian sehingga memilih untuk bekerja di luar sektor pertanian. Tipe kedua adalah rumahtangga yang mempunyai pendapatan dari sektor pertanian namun tidak dijadikan sebagai pendapatan utama.

Diversifikasi nafkah atau pola nafkah ganda yaitu penerapan berbagai aktivitas nafkah dengan cara mencari pekerjaan lain selain pertanian untuk menambah pendapatan atau mengerahkan anggota rumahtangga lain untuk ikut bekerja (selain di sektor pertanian). Rumahtangga yang melakukan strategi ini umumnya adalah yang menguasai lahan garapan sempit sehingga pendapatan pertanian rendah. Diversifikasi nafkah sebenarnya meliputi strategi lain seperti strategi rekayasa spasial, intensifikasi sektor non pertanian, pemanfaatan remitan, pemanfaatan modal sosial, dan investasi. Strategi ini dilakukan sebagai bentuk strategi bertahan hidup dengan mengandalkan banyak sektor sebagai sumber pendapatan.

Rekayasa spasial atau migrasi merupakan strategi merupakan usaha rumahtangga untuk mendapatkan pekerjaan dengan melakukan mobilitas ke daerah lain di luar desa, baik secara permanen maupun sirkuler. Migrasi dilakukan karena lapangan pekerjaan di desa tidak sebanyak di kota. Aktivitas nafkah yang dapat mereka lakukan di desa hanya bertani. Sedangkan faktanya pekerjaan tani semakin hari semakin tidak diminati khusunya kaum muda. Mereka lebih memilih untuk bekerja di kota sebagai buruh. Pekerjaan ini dirasa bisa memberi pendapatan yang lebih banyak. Strategi migrasi dilakukan rumahtangga secara sirkuler atau permanen.

Pemanfataan modal sosial yaitu memanfaatkan modal sebagai akses untuk memperoleh pendapatan. Modal sosial dapat memberikan jaminan bagi rumahtangga saat menghadapi kesulitan keuangan atau dapat menyediakan kesempatan kerja bagi rumahtangga. Modal sosial yang sering digunakan rumahtangga adalah kekuatan hubungan dengan sesama anggota masyarakat dan keterlibatan dalam perkumpulan sosial. Rumahtangga di pedesaaan umumnya memang sangat bergantung dengan modal sosial ini karena dirasa telah memberi banyak manfaat dalam kehidupan.

Pemanfaatan remitan yaitu memanfaatkan kiriman uang dari anggota rumahtangga lain yang bekerja di luar kota. Jenis remitan ini terdiri atas remitan yang sifatnya rutin dan remitan yang hanya sesekali. Penerima remitan rutin biasanya adalah golongan tua dan bekerja di sektor pertanian saja. Anak mengirimkan uang sebagai tambahan untuk kebutuhan hidup orang tua di desa. Rumahtangga lain penerima remitan rutin adalah yang dititipi cucu anaknya yang bekerja di kota. Pada rumahtangga ini biasanya remitan rutin mengirim uang untuk keperluan seharihari. Penerimaan remitan tidak rutin adalah mereka muda dan dapat melakukan pekerjaan di luar sektor pertanian. Biasanya mereka hanya saat butuh uang lebih atau harihari besar seperti lebaran.

Investasi yaitu mengacu pada pembentukan aset yang dapat digunakan untuk sumber nafkah pada masa yang akan datang. Strategi inilah yang dapat menyelamatkan rumahtangga dari keterpurukan dan kelaparan saat krisis atau guncangan. Investasi yang banyak dilakukan adalah dengan memelihara hewan ternak. Menamani lahan dengan tanaman kayu juga merupakan bentuk strategi investasi yang dilakukan rumahtangga. Bagi rumahtangga dengan pendapatan tinggi atau mereka yang intensif pada sektor non pertanian biasanya berinvestasi dengan membeli barang berharga seperti lahan, emas, kendaraan, dan sebagainya yang dapat diuangkan lagi. Bentuk investasi lain yang dilakukan rumahtangga adalah dengan menyekolahkan anak dan membina hubungan baik dengan sesama anggota masyarakat. Membina hubungan baik dapat dilakukan dengan selalu ikut dalam perkumpulan sosial, menjenguk orang sakit, melayat orang meninggal, dan menghadiri hajatan.

Hubungan antara modal nafkah dan strategi nafkah adalah tindakan nafkah yang dilakukan berkaitan dengan pemanfaatan penggunaan modal nafkah. Semakin banyak modal yang dimiliki mengakibatkan banyak modal nafkah yang dapat dimanfaatkan sehingga semakin banyak strategi yang dilakukan. Namun bagi rumahtangga yang tidak memiliki atau hanya memiliki dalam kategori rendah suatu modal, mereka berupaya untuk memaksimalkan penggunaan modal tersebut. Hal ini terlihat pada kasus rumahtangga lapisan bawah yang menguasai lahan sempit tidak akan menerapkan strategi intensifikasi pendapatan pertanian. Mereka umumnya akan lebih intensif pada pendapatan non pertanian atau melakukan strategi diversifikasi nafkah dengan memanfaatkan anggota rumahtangga lain untuk bekerja di luar sektor pertanian atau migrasi. Rumahtangga akan mendapatkan penghasilan yang berasal dari berbagai sumber.

Mayoritas rumahtangga di kedua desa menerapkan strategi diversifikasi nafkah atau pola nafkah ganda. Jarang sekali rumahtangga yang hanya intensif pada sektor pertanian saja. Mereka yang intensif pada sektor pertanian adalah rumahtangga kelompok usia tua yang sudah tidak mempunyai tanggungan. Strategi ini merupakan bentuk dari pertahan rumahtangga untuk menghasilkan pendapatan di luar sektor pertanian. Aktivitas di sektor pertanian saja dirasa tidak mampu untuk menopang kebutuhan 
rumahtangga. Strategi ini meliputi lima strategi lainnya.

\section{Struktur Nafkah Rumahtangga Petani Hutan Rakyat}

Struktur nafkah adalah komposisi pendapatan rumahtangga dari berbagai aktivitas nafkah yang dilakukan oleh seluruh anggota rumahtangga. Pendapatan terbagi menjadi menjadi pendapatan uang tunai (in cash) atau bentuk kontribusi lain (in kind) untuk kesejahteraan material individu atau keluarga yang diperoleh dari berbagai kegiatan memenuhi nafkah (Ellis 2000). Pendapatan terbagi menjadi tiga sumber yaitu pendapatan farm yaitu pendapatan yang diperoleh dari aktivitas nafkah di sektor pertanian secara luas berupa hasil panen, hasil penjualan ternak, dan hasil buruh tani. Kedua adalah pendapatan non-farm yaitu pendapatan yang diperoleh dari aktivitas nafkah di luar sektor pertanian meliputi upah buruh selain buruh tani, perdagangan, industri, gaji PNS, remitan, jasa, dan bantuan. Ketiga adalah pendapatan kayu yaitu pendapatan yang diperoleh dari hasil penjualan kayu. Berikut adalah struktur nafkah rumahtangga.

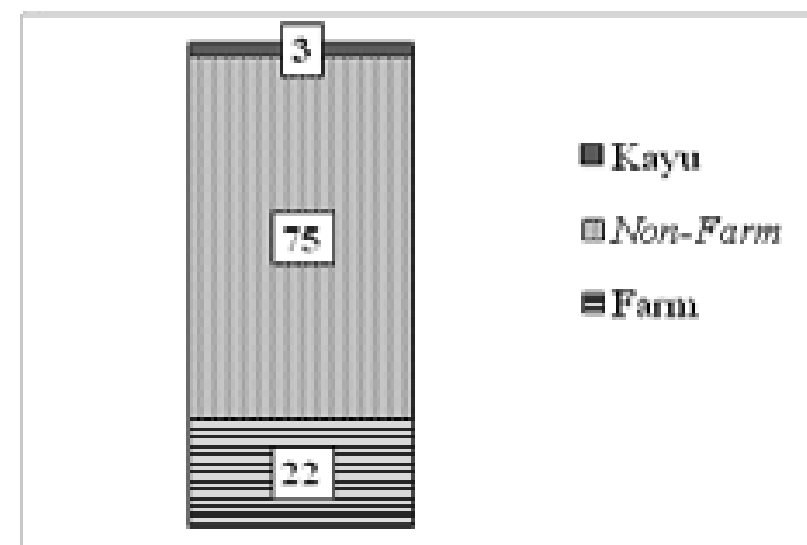

Sumber: Data primer

Gambar 2 Struktur nafkah rumahtangga responden di Desa Sejati dan Desa Selomarto tahun 2014-2014 (\%)

Pendapatan rumahtangga di kedua desa secara keseluruhan masih didominasi pendapatan non-farm yang mencapai 75\% atau sekitar Rp18 402 405, sedangkan pendapatan farm menyumbang Rp5 237193 atau sekitar 22\%. Dapat dikatakan bahwa rumahtangga di kedua desa bukan merupakan rumahtangga petani murni walaupun mereka masing-masing memiliki lahan garapan untuk bercocok tanam. Mayoritas rumahtangga merasa pendapatan farm dirasa kurang dapat memenuhi kebutuhan sehingga banyak yang beralih memanfaatkan sektor non pertanian. Seluruh rumahtangga mendapatkan penghasilan dari sektor non pertanian, sedangkan ada beberapa rumahtangga yang tidak memperoleh pendapatan farm.

Pendapatan kayu secara keseluruhan hanya menyumbang Rp755 582 atau 3\% dari pendapatan keseluruhan. Hal ini dikarenakan hanya sedikit rumahtangga yang menebang dan menjual kayu dalam rentang setahun belakangan ini. Alasan penebangan dan penjualan kayu yang dilakukan rumahtangga adalah untuk menutupi biaya sehari-hari, menunjang kegiatan pertanian seperti membeli pupuk, biaya kebutuhan mendadak seperti biaya berobat dan untuk merenovasi rumah serta karena umur kayu dirasa sudah terlalu tua.

Sama halnya dengan penelitian yang dilakukan Handoko (2007) pada rumahtangga petani di Kecamatan Jatirogo, Tuban. Pendapatan yang diperoleh dari hutan rakyat (kayu) hanya menyumbangkan $6,12 \%$ terhadap pendapatan total rumahtangga. Hasil tersebut memberikan bukti bahwa petani tidak menebang dan menjual hasil hutannya secara besar-besaran. Pengambilan hasil dari hutan rakyat dilakukan apabila sumber-sumber lain tidak bisa digunakan untuk memenuhi kebutuhan tertentu atau yang disebut dengan daur butuh. Namun demikian pendapatan kayu sangat menolong terutama mereka yang tidak mempunyai tabungan atau aset berharga lain jika ada keperluan mendadak.

Rata-rata penghasilan rumahtangga di kedua desa per tahun adalah Rp24 408 533. Pendapatan rumahtangga dapat diklasifikasikan menjadi pendapatan tinggi, sedang, dan rendah berdasarkan perhitungan yang telah dilakukan. Berikut adalah tingkat pendapatan rumahtangga.

Tabel 1. Pendapatan rumahtangga responden di Desa Sejati dan Desa Selomarto tahun 2013-2014 (Rp)

\begin{tabular}{lcrrr}
\hline \multirow{2}{*}{ Pendapatan } & \multicolumn{2}{c}{ Sejati } & \multicolumn{2}{c}{ Selomarto } \\
\cline { 2 - 5 } & $\mathrm{n}$ & $\%$ & $\mathrm{n}$ & \multicolumn{1}{c}{$\%$} \\
\hline Tinggi $(\geq 35$ 19430) & 3 & 10 & 7 & 23 \\
Sedang (13 622767-35 & 16 & 53 & 10 & 33 \\
194300) & & & & \\
Rendah $(\leq 13622766)$ & 11 & 37 & 13 & 44 \\
Total & 30 & 100 & 30 & 100 \\
Sumber: Data primer & & & &
\end{tabular}

Berdasarkan Tabel 1, jumlah rumahtangga dengan pendapatan $\geq$ Rp35 194301 lebih banyak berada di Desa Selomarto yaitu sekitar 23\%, sedangkan di Desa Sejati hanya $10 \%$. Namun terlihat bahwa rumahtangga di Desa Selomarto didominasi oleh rumahtangga dengan tingkat pendapatan rendah. Hal ini menunjukkan bahwa tingkat kesenjangan di Desa Selomarto lebih tinggi karena rumahtangga di dengan pendapatan tinggi lebih banyak namun di sisi lain rumahtangga dengan pendapatan rendah juga mendominasi. Rumahtangga dengan pendapatan tinggi di kedua desa adalah mereka yang intensif pada non pertanian seperti berdagang, wiraswasta, dan pegawai negeri.

Pendapatan dari usaha-usaha tersebut sangat besar jika dibanding dengan pendapatan dari usaha pertanian. Pendapatan rumahtangga dengan kategori rendah adalah mereka yang intensif pada pertanian dan mendapatkan pendapatan non-farm dari remitan. Rumahtangga yang seperti ini merupakan rumahtangga golongan usia tua yang sudah tidak lagi mempunyai tanggungan dan mempunyai anak yang bekerja di luar daerah. Mereka umumnya memilih untuk intensif pada pertanian untuk memenuhi kebutuhan.

Strategi nafkah yang diterapkan rumahtangga berhubungan dengan struktur nafkahnya. Terlihat bahwa penyumbang terbesar dalam pendapatan rumahtangga berasal dari sektor non pertanian yang mencapai $75 \%$. Hal ini menunjukkan bahwa rumahtangga yang intensif pada sektor non 
pertanian memiliki tingkat pendapatan yang lebih tinggi daripada mereka yang hanya intensif pada sektor pertanian. Pendapatan non-farm sebagai penyumbang terbesar dalam pendapatan rumahtangga ini dikarenakan semua rumahtangga di kedua desa memperoleh pendapatan nonfarm. Mereka yang intensif pada sektor pertanian tak lantas tidak mendapatakan pendapatan non-farm. Rumahtangga intensif pada sektor pertanian selain bekerja di sektor pertanian mereka banyak yang memperoleh pendapatan non-farm seperti dari penerimaan remitan. Pemanfaatan remitan merupakan salah satu strategi nafkah yang khas rumahtangga di kedua desa atau rumahtangga di Kabupaten Wonogiri pada umumnya.

Rumahtangga yang intensif pada pendapatan non pertanian juga tak lantas tidak memperoleh pendapatan farm dan kayu. Sebagian besar rumahtangga yang intensif pada non pertanian tetap mengolah lahan mereka sehingga dapat menghasilkan panen. Aktivitas non-farm yang mereka lakukan tidak terikat oleh waktu seperti sebagai buruh atau pedagang sehingga mereka dapat meluangkan waktu untuk mengolah lahan. Aktivitas farm ini walaupun bukan sebagai pekerjaan yang dapat menghasilkan pendapatan besar namun sulit untuk ditinggalkan rumahtangga. Bagi mereka hasil panen dari mengolah lahan menjadi pendapatan yang khas dari rumahtangga di pedesaan sehingga tetap harus ada.

Secara umum rumahtangga di kedua desa tidak hanya melakukan satu aktivitas nafkah saja melainkan beragam, sehingga mereka banyak memperoleh pendapatan dari berbagai sumber. Selain itu pengerahan anggota rumahtangga lain selain kepala rumahtangga untuk bekerja mengakibatkan pendapatan rumahtangga semakin besar.

\section{Resiliensi Nafkah Rumahtangga Petani Hutan Rakyat}

Resiliensi adalah kemampuan rumahtangga untuk bertahan dari guncangan atau krisis. Tingkat resiliensi dilihat dari waktu yang diperlukan rumahtangga untuk kembali ke posisi normal jika terjadi guncangan. Waktu yang diperlukan rumahtangga untuk kembali normal bervariasi antara tidak lebih dari satu bulan hingga lebih dari enam bulan. Berikut adalah tingkat resiliensi rumahtangga di Desa Sejati dan Desa Selomarto.

Tabel 2. Tingkat resiliensi rumahtangga responden di Desa Sejati dan Desa Selomarto tahun 2013-2014

\begin{tabular}{lrrrr}
\hline \multirow{2}{*}{ Tingkat resiliensi } & \multicolumn{2}{c}{ Sejati } & \multicolumn{2}{c}{ Selomarto } \\
\cline { 2 - 5 } & \multicolumn{1}{c}{$\mathrm{N}$} & \multicolumn{1}{c}{$\%$} & \multicolumn{1}{c}{ n } & \multicolumn{1}{c}{$\%$} \\
\hline Tinggi (<3 bulan) & 9 & 30 & 8 & 27 \\
Sedang (3-6 bulan) & 16 & 53 & 19 & 63 \\
Rendah ( $>$ 6 bulan) & 5 & 17 & 3 & 10 \\
Total & 30 & 100 & 30 & 100 \\
Sumber: Data primer & & & &
\end{tabular}

Tabel 2 menunjukkan bahwa tingkat resiliensi rumahtangga di kedua desa relatif sama. Tingkat resiliensi ini menunjukkan bahwa baik di Desa Sejati maupun Desa Selomarto rata-rata adalah sedang Ada sekitar 28\% rumahtangga yang mempunyai tingkat resiliensi tinggi dan $13 \%$ atau delapan rumahtangga yang mempunyai resiliensi rendah. Rumahtangga dengan tingkat resiliensi tinggi yang hanya memerlukan waktu kurang dari tiga bulan untuk kembali ke posisi semula merupakan rumahtangga yang intensif pada pendapatan non pertanian dimana mereka mendapatkan pendapatan yang rutin dan relatif besar. Pendapatan tersebut yang kemudian ditabung atau diinvestasikan dalam bentuk barang sehingga jika sewaktuwaktu perlu uang banyak bisa digunakan.

Tingkat resiliensi sedang pada rumahtangga biasanya adalah mereka yang menunggu hasil panen (sekitar empat bulan) untuk mendapatkan uang yang bisa digunakan untuk mengembalikan pinjaman saat rumahtangga mengalami krisis ekonomi. Rumahtangga yang memiliki tingkat resiliensi rendah biasanya mereka yang tidak memiliki tabungan, pendapatan farm maupun non-farm rendah sehingga hanya sedikit cara alternatif yang dapat dilakukan jika rumahtangga mengalami guncangan. Waktu yang digunakan untuk kembalike posisi normal yang diperlukan rumahtangga pada tingkat resiliensi rendah juga relatif lama. Walaupun begitu, rumahtangga baik yang berada di Desa Sejati maupun Desa Selomarto merupakan rumahtangga yang mempunyai kemampuan untuk bertahan hidup jika dilanda krisis atau guncangan ekonomi.

Bentuk resiliensi nafkah yang dilakukan oleh rumahtangga adalah sebagai berikut:

Penggunaan tabungan sebagai alternatif yang dapat diandalkan oleh rumahtangga saat kondisi krisis. Rumahtangga yang mempunyai tabungan dalam bentuk uang yang relatif besar besar merupakan rumahtangga yang intensif pada non pertanian seperti PNS karena setiap penghasilannya menentu. Sedangkan rumahtangga lain adalah para bakul kayu dan pedagang. Pendapatan yang tinggi juga diimbangi dengan tabungan yang tinggi pula. Pengelolaan pendapatan menjadi faktor penting untuk rumahtangga agar tetap bisa bertahan.

Pemanfaatan modal sosial yang merupakan hal yang penting bagi rumahtangga di pedesaan. Modal sosial diperoleh dari bantuan tetangga sekitar, sanak saudara, kerabat, atau jaringan. Bagi rumahtangga di kedua desa modal sosial sangat membantu mereka baik untuk kebutuhan kecil seperti untuk membayar uang sekolah anak hingga keperluan biaya berobat. Modal sosial juga memberi peranan penting dalam kehidupan masyarakat di kedua desa ini. Modal sosial membantu rumahtangga untuk mendapatkan pendapatan baik secara in-kind maupun incash. Antar sesama warga umumnya saling bergantian meminjam uang atau beras. Jika ada rumahtangga yang mempunyai makanan berlebih tidak segan-segan untuk memberi kepada tetangga. Modal sosial juga dapat berupa akses terhadap pekerjaan.

Pemanfaatan akses pekerjaan di dalam dan luar desa dilakukan rumahtangga saat mengalami krisis ekonomi atau saat musim kemarau panjang, sektor pertanian tidak lagi menjadi sumber pendapatan yang menjanjikan untuk menopang kebutuhan. Rumahtangga yang masih mempunyai tanggungan anak sekolah umumnya melakukan migrasi bekerja di kota. Selain akses pekerjaan di luar daerah, rumahtangga juga dapat memanfaatkan akses pekerjaan di dalam desa. Pekerjaan tersebut seperti buruh tani, buruh bangunan, buruh industri atau buruh cuci. Kesempatan kerja ini diperoleh berdasarkan atas kepercayaan antara pemberi kerja dengan pekerja. 
Hewan ternak sebagai aset berharga bagi rumahtangga. Bagi rumahtangga yang mempunyai hewan ternak dan hanya mempunyai kayu sedikit mereka lebih memilih untuk menjual hewan ternaknya sebagai alternatif pertama jika butuh uang. Hal ini dikarenakan hewan lebih cepat untuk tumbuh dibanding dengan kayu. Jika hewan ternak dijual untuk suatu keperluan atau memang umur ternak sudah tua, rumahtangga tidak lantas menggunakan semua uangnya. Mereka menyisihkan uang hasil penjualan tersebut untuk membeli hewan yang berumur muda yang umurnya relatif lebih murah. Namun jika hewan dijual untuk keperluan mendadak dan tidak lagi menyisakan uang, sistem gado menjadi alternatif agar rumahtangga tetap bisa memiliki ternak.

Pemanfaatan kiriman remitan sebagai salah satu alternatif rumahtangga baik dalam kondisi terdesak atau normal. Biasanya remitan dikirimkan anak yang bekerja di kota. Anak yang bekerja di kota tidak semua mengirimkan uangnya secara rutin setiap bulan. Hal ini dikarenakan mereka sudah berumahtangga. Namun jika sedang membutuhkan uang mendadak pasti akan dibantu. Terutama jika orang tua sakit sehingga perlu biaya berobat hingga operasi.

Penjualan barang berharga merupakan bentuk resiliensi yang banyak dilakukan oleh rumahtangga pendapatan tinggi atau yang intensif pada sektor non pertanian. Barang berharga ini meliputi perhiasan, lahan atau rumah, kendaraan atau barang investasi lain yang dapat digunakan sebagai tabungan. Barang yang menjadi tabungan rumahtangga adalah emas dan lahan karena keduanya memiliki nilai jual yang terus naik. Jika ada keperluan mendadak yang cukup besar biasanya rumahtangga menjual emasnya.

Penjualan kayu sebagai salah satu aset yang dimiliki semua rumahtangga di kedua desa. Seperti yang telah dipaparkan pada bab sebelumnya kegunaan kayu di hutan rakyat milik rumahtangga sebagai aset yang dapat dijual sewaktu-waktu. Kayu merupakan salah satu komoditas yang mempunyai liquiditas tinggi. Kayu sangat mudah untuk dijual sama seperti emas yang banyak dijadikan aset bagi rumahtangga perkotaan. Aset atau sumberdaya ini adalah sesuatu yang khas yang dimiliki rumahtangga.

Hubungan kepemilikan modal nafkah dan pendapatan dengan resiliensi. Resiliensi nafkah rumahtangga dipengaruhi oleh kepemilikan modal nafkah dan pendapatan. Semakin tinggi tingkat kepemilikan modal nafkah dan tingkat pendapatan maka semakin tinggi tingkat resiliensi rumahtangga. Secara umum kelima modal dan pendapatan berhubungan dengan resiliensi rumahtangga. Berdasarkan hasil uji hubungan terlihat bahwa modal yang tidak menyatakan hubungan nyata dengan resiliensi adalah modal manusia dimana sig 0,624 $(>0,01)$. Hal ini dikarenakan modal manusia seperti tingkat pendidikan, umur, dan keterampilan tidak berpengaruh besar terhadap aktivitas nafkah dan pendapatan rumahtangga. Mayoritas rumahtangga bekerja sebagai petani dan buruh. Bagi mereka tingkat pendidikan tidak memberi pengaruh yang signifikan terhadap usaha tani mereka. Petani yang tidak pernah bersekolah akan sama dengan petani tamatan SMP, begitu juga sebagai buruh. Tingkat pendidikan yang sedikit berpengaruh terhadap aktivitas nafkah adalah tingkat pendidikan tinggi yaitu SMA, mereka umumnya bekerja pada usaha yang mendatangkan penghasilan besar seperti PNS dan wiraswasta. Namun responden dengan tingkat pendidikan tinggi tidak lebih dari 15\%.

Hubungan antara modal fisik, alam, sosial, dan finansial dengan tingkat resiliensi memiliki hubungan nyata (sig $<0,01$ ). Pada modal finansial menunjukkan kekuatan hubungan kuat (nilai koefisien 0,507). Modal finansial seperti akses terhadap pinjaman, penerimaan remitan, dan tabungan dapat digunakan rumahtangga untuk mendapatkan uang jika memerlukan dalam jumlah relatif besar. Sedangkan modal fisik, alam, dan sosial menyatakan hubungan moderat (nilai koefisien antara 0,354 hingga 0,412). Modal fisik (lahan,kendaraan bermotor, dan hewan ternak) dan modal alam (kayu) dapat dijual jika sewaktuwaktu rumahtangga perlu uang. Barang-barang tersebut dijadikan aset oleh rumahtangga yang juga dianggap sebagai tabungan.

Pada modal sosial yang meliputi jaringan dan hubungan dapat dimanfaatkan untuk berhutang. Modal sosial juga dapat menunjang modal finansial seperti pemanfaatan akses terhadap pinjaman. Kekuatan hubungan dan kepemilikan jaringan mempengaruhi rumahtangga mendapatkan akses terhadap pinjaman. Namun tingkat kepemilikan semua modal nafkah menunjukkan hubungan yang kuat (nilai koefisien 0,619) terhadap resiliensi. Hal ini menunjukkan bahwa kepemilikan modal nafkah sangat berpengaruh terhadap resiliensi rumahtangga.

Resiliensi rumahtangga selain dipengaruhi oleh modal nafkah juga dipengaruhi oleh pendapatan. Pendapatan rumahtangga terdiri dari pendapatan farm, pendapatan non-farm, dan pendapatan kayu. Hasil uji hubungan menyatakan bahwa tingkat pendapatan berhubungan dengan tingkat resiliensi (sig <0,000). Kekuatan hubungan menyatakan hubungan kuat (nilai koefisien 0,618). Hal ini menunjukkan bahwa semakin tinggi tingkat pendapatan maka semakin tinggi pula tingkat resiliensi. Pendapatan yang tinggi dapat mempengaruhi kemampuan rumahtangga untuk menabung, tabungan tersebut yang nantinya dapat digunakan rumahtangga sebagai penolong saat rumahtangga mengalami krisis.

Peranan hutan rakyat dan modal sosial dalam resiliensi nafkah. Hutan rakyat nyatanya telah memberi manfaat besar bagi rumahtangga di Desa Sejati maupun Desa Selomarto pada khususnya. Selain dari aspek ekologi dan sosial, manfaat yang dirasakan oleh rumahtangga adalah manfaat secara ekonomi. Hutan rakyat telah memberikan penghidupan bagi sebagian besar rumahtangga baik secara langsung maupun tidak langsung. Pendapatan nyata yang diperoleh dari hutan rakyat adalah hasil dari penjualan kayu rakyat. Persentase pendapatan kayu memang hanya menyumbang 3\% dari total dari keseluruhan pendapatan rumahtangga, namun nyatanya pendapatan tersebut dapat menolong rumahtangga jika membutuhkan uang yang relatif besar. Orientasi penanaman kayu yang dilakukan rumahtangga memang bukan untuk memenuhi kebutuhan sehari-hari melainkan untuk keperluan mendadak. Kayu diperlakukan sebagai aset atau tabungan rumahtangga seperti kisah Bapak Tkrn, 70 tahun:

"Bapak Tkrn merupakan seorang petani sejak dulu. Saat ini dia memiliki lahan sendiri berupa sawah satu kotak dan tegalan lima kotak (lebih dari dua hektar). Sawahnya ditanami padi, jagung, dan kedelai masingmasing satu kali dalam setahun. Pekerjaan lain yang dia lakukan bersama istrinya adalah sebagai buruh 
tani dengan ikut mengolah beberapa sawah tetangga dan mengurus dua ekor sapi miliknya.

Pendapatan yang mereka peroleh dari hasil dari kegiatannya tersebut sekitar Rp6 880000 per tahun atau Rp18 000 per hari. Walaupun kecil, pendapatan tersebut dirasa cukup untuk memenuhi kebutuhan hidup berdua dengan istrinya. Dia hanya mempunyai satu anak yang sekarang sudah berumahtangga dan tinggal di luar kecamatan. Saat rumahtangga mengalami krisis ekonomi mereka tidak akan merasa terpuruk.

Hal ini dikarenakan mereka mempunyai cadangan kayu. Tegalan dia tanami kayu jenis jati yang jumlahnya lebih dari 100 pohon. Selain itu mereka juga mempunyai stok kayu yang sudah ditebang. Sekitar beberapa tahun yang lalu kayu tersebut sudah ditawar bakul dengan harga yang relatif besar. Kayu tersebut akan mereka jual jika benar-benar membutuhkan uang dengan jumlah yang besar. Alasan utama dia membudidayakan kayu adalah sebagai tabungan untuk anak cucunya kelak".

Kasus Bapak Tkrn merupakan gambaran kondisi rumahtangga di kedua desa. Kayu dapat dijadikan pegangan terutama bagi rumahtangga berpenghasilan rendah. Walau menjual kayu bukan menjadi sumber penghasilan utama, namun dengan memiliki kayu mereka merasa aman. Jika ada kebutuhan mendadak yang relatif besar kayu dapat diandalkan. Kayu merupakan salah satu menopang resiliensi nafkah rumahtangga yang khas di kedua desa.

Pendapatan lain yang diperoleh dari hutan rakyat adalah pendapatan yang diperoleh saat menjadi buruh penggergajian atau buruh angkut saat ada pemanenan kayu. Selain itu hasil dari tanaman lain seperti palawija, buahbuahan, sayur-sayuran dan empon-empon yang ditanam di sekitar rumah dapat digunakan rumahtangga untuk konsumsi sehari-hari. Hal ini juga yang menyebabkan rumahtangga di kedua desa terhindar dari kelaparan karena mereka mempunyai cadangan makanan yang bisa diperoleh tanpa mengeluarkan uang. Tanaman pangan tersebut membantu rumahtangga mengurangi biaya pengeluaran. Jika hasil panen relatif banyak maka biasanya dijual sehingga menghasilkan uang.

Faktor lain yang menyebabkan rumahtangga di kedua desa ini mempunyai resiliensi adalah tingginya kepemilikan modal sosial. Modal sosial yang meliputi kekuatan hubungan, jaringan, dan keterlibatan dalam perkumpulan sosial nyatanya telah memberi banyak manfaat bagi kehidupan rumahtangga. Hubungan sosial antar sesama masyarakat menunjukkan gambaran masyarakat desa pada umumnya yang masih sangat erat. Hubungan ini terus dibina semua warga agar tetap selalu ada. Pada bab strategi nafkah juga telah dijelaskan bahwa strategi investasi rumahtangga dilakukan dengan salah satu caranya adalah menegmbangkan modal sosial.

Modal sosial telah banyak membantu rumahtangga saat dilanda musibah. Saat ada warga yang butuh uang untuk biaya berobat dalam jumlah relatif besar, para tetangga lain secara sukarela membantu mengumpulkan iuran. Begitu juga saat rumahtangga menggelar hajatan, para tetangga lain juga ikut membantu baik berupa tenaga, pikiran, waktu, dan uang. Hal ini yang menyebabkan rumahtangga tetap bisa bertahan walaupun secara pendapatan masih banyak yang berada di bawah garis kemiskinan. Modal sosial telah memberikan jaminan rasa aman secara baik secara sosial dan finansial karena mereka percaya warga lain akan membatu jika dirinya mengalami kesulitan.

\section{PENUTUP}

\section{Kesimpulan}

Berdasarkan hasil penelitian yang diperoleh maka dapat ditarik kesimpulan yang mengacu pada tujuan penelitian sebagai berikut:

1. Modal nafkah yang dimiliki rumahtangga di kedua desa penelitian adalah modal manusia, fisik, alam, finansial, dan sosial. Modal manusia meliputi usia, tingkat pendidikan, keterampilan, dan alokasi pekerja dalam rumahtangga. Modal fisik terdiri atas penguasaan lahan, kepemilikan kendaraan bermotor, dan kepemilikan hewan ternak. Modal alam dilihat dari kepemilikan kayu. Modal finansial terdiri atas kemampuan menabung, akses terhadap pinjaman, dan pemerimaan remitan. Modal sosial terdiri atas kekuatan hubungan, keterlibatan dalam perkumpulan, dan kepemilikan jaringan. Modal terbesar yang dimiliki rumahtangga adalah modal sosial. Kelima modal dimainkan rumahtangga sedemikian rupa dalam bentuk strategi nafkah.

2. Strategi nafkah yang dibangun rumahtangga adalah strategi intensifikasipendapatan pertanian, intensifikasi pendapatan non pertanian, diversifikasi nafkah atau pola nafkah ganda, rekayasa spasial atau migrasi, pemanfataan modal sosial, pemanfaatan remitan dan strategi investasi. Strategi nafkah ini berdampak pada struktur nafkah yaitu tingkat pendapatan rumahtangga.

3. Struktur nafkah rumahtangga terdiri atas pendapatan farm, pendapatan non-farm, dan pendapatan kayu. Pendapatan non-farm menyumbang $75 \%$, kemudian pendapatan farm $22 \%$ dan kayu hanya $3 \%$. Pendapatan non-farm tinggi karena banyak rumahtangga melakukan aktivitas di luar sektor pertanian untuk memperbaiki kehidupannya. Sedangkan pendapatan kayu sangat rendah dikarenakan penjualan kayu tidak rutin dilakukan rumahtangga. Mereka hanya akan menjual kayu jika dalam kondisi tertentu.

4. Semua rumahtangga di kedua desa merupakan rumahtangga yang mempunyai kemampuan untuk bertahan hidup jika dilanda krisis atau guncangan ekonomi. Tidak ada rumahtangga yang terpuruk atau mengalami kelaparan jika terjadi krisis atau guncangan dalam hidupnya. Hal ini disebabkan oleh rumahtangga tidak hanya mempunyai sumber pendapatan dari satu sektor saja, umumnya mereka menerapkan strategi pola nafkah ganda. Bentuk resiliensi rumahtangga cukup beragam yaitu penggunaan tabungan, pemanfaatan modal sosial, pemanfaatan remitan, pemanfaatan akses pekerjaan di dalam ataupun luar desa, penjualan ternak, penjualan barang berharga, dan penjualan kayu. Peranan hutan rakyat dalam menopang resiliensi nafkah rumahtangga adalah hutan rakyat dapat menghasilkan pendapatan dari kayu, tanaman pangan, dan empon-empon. Pendapatan kayu dirasa sebagai penolong rumahtangga saat memerlukan uang 
dalam jumlah besar. Faktor lain yang menyebabkan rumahtangga mempunyai resiliensi adalah tingginya kepemilikan modal sosial. Modal sosial telah banyak membantu rumahtangga saat dilanda musibah.

\section{Saran}

1. Melihat posisi petani yang masih lemah dalam proses pemasaran kayu rakyat hendaknya pemerintah atau instansi terkait untuk membuat perundang-undangan atau peraturan dalam mengatur sistem penjualan kayu agar dapat menguntungkan kedua belah pihak.

2. Perlu adanya pembentukan (di Desa Selomarto) dan pengaktifan kembali kelompok tani yang sebelumnya sudah ada (Di Desa Sejati) kelembagaan atau organisasi yang dapat menaungi petani agar petani dapat memiliki bargaining position dalam penentuan harga jual kayu dan harga jual komoditi pertanian lainnya.

3. Resiliensi rumahtangga di kedua desa ditopang oleh kelima modal. Modal tertinggi yang dimiliki oleh rumahtangga adalah modal sosial. Maka modal sosial khususnya hubungan antar sesama anggota masyarakat harus terus dipertahankan.

\section{DAFTAR PUSTAKA}

[RI] Pemerintah Republik Indonesia. 1967. UndangUndang Republik Indonesia Nomor 5 Tahun 1967 tentang Ketentuan-Ketentuan Pokok Kehutanan. Jakarta (ID): Sekretariat Negara

[RI] Pemerintah Republik Indonesia. 1999. UndangUndang Republik Indonesia Nomor 41 Tahun 1999 tentang Kehutanan. Jakarta (ID): Sekretariat Negara

Aryadi M. 2012. Hutan Rakyat: Fenomenologi Adaptasi Budaya Masyarakat. Malang (ID):UMM Press

Adger NW. 2000. Social and ecological resilience: are they related?. Progress in Human Geography. [Internet]. [Diunduh 4 Juni 2014]. Vol.24 No.3. Tersedia pada https://groups.nceas.ucsb.edu/sustainabilityscience/

Daniyati E. 2009. Efektivitas sistem sertifikasi pengelolaan hutan di hutan rakyat (studi kasus di Kabupaten Wonogiri Provinsi Jawa Tengah dan Kabupaten Kulon Progo Provinsi DI. Yogyakarta) [tesis]. Bogor (ID): Institut Pertanian Bogor

Ellis F. 2000. Rural Livelihood Diversity in Developing Country. London (UK): Oxford University Press

Fridayanti N. 2013. Analisis struktur dan strategi nafkah rumahtangga petani sekitar kawasan hutan konservasi di Desa Cipeuteuy Kabupaten Sukabumi [skripsi]. Bogor (ID): Institut Pertanian Bogor

Handoko AD. 2007. Sistem pengelolaan dan kontribusi hutan rakyat terhadap pendapatan rumahtangga petani (kasus di Kecamatan Jatirogo, Kabupaten Tuban, Jawa Timur) [skripsi]. Bogor (ID): Institut Pertanian Bogor

Hinrichs A, Muhtaman DR, Irianto N. 2008. Sertifikasi hutan rakyat di Indonesia. [Internet]. [Diunduh 18 Januari 2014]. Tersedia pada http://www.xa.yimg. com

Marwoto. 2012. Peranan modal sosial masyarakat dalam pengelolaan hutan rakyat dan perdagangan kayu rakyat (kasus di Kecamatan Giriwoyo Kabupaten Wonogiri) [tesis]. Bogor (ID): Institut Pertanian Bogor

Prasetya AR. 2013. Struktur dan strategi nafkah rumahtangga petani peserta program pengelolaan hutan bersama masyarakat (PHBM) di Bogorejo [skripsi]. Bogor (ID): Institut Pertanian Bogor

Purbayu BS, Ashari. Analisis Statistik dengan Microsoft Excel \& SPSS. Yogyakarta (ID): Andi Publisher

Purnomo AM. 2006. Strategi nafkah rumahtangga desa sekitar hutan studi kasus desa peserta phbm (pengelolaan hutan bersama masyarakat) di Kabupaten Kuningan Jawa Barat [tesis]. Bogor (ID): Institut Pertanian Bogor

Salim. 2004. Dasar-Dasar Hukum Kehutanan. Jakarta (ID): Sinar Grafika

Singarimbun M, Effendi S. 2008. Metode Penelitian Survei. Jakarta (ID): LP3ES

Turasih. 2011. Sistem nafkah rumahtangga petani kentang di dataran tinggi dieng (kasus Desa Karangtengah, Kecamatan Batur, Kabupaten Banjarnegara, Provinsi Jawa Tengah) [skripsi]. Bogor (ID): Institut Pertanian Bogor

Walker B, Holling CS, Carpenter SP, Kinzig A. 2004. Resilience, adaptability, and transformability in social-ecological system. Economy and Society. Vol.9. No.2. [Internet]. [Diunduh 26 Februari 2014]. Tersedia pada: http://www.ecologyandsociety.org

Wardhana GW. 2008. Persepsi pelaku dan non pelaku pemanenan terhadap kegiatan pemanenan kayu di hutan rakyat serta peranan kegiatan pemanenan kayu di hutan rakyat terhadap kontribusi pendapatan rumahtangga pelaku pemanenan (kasus di Kecamatan Tamansari dan Cigudeg, Bogor Jawa Barat) [skripsi]. Bogor (ID): Institut Pertanian Bogor

Widiyanto. 2009. Straregi nafkah rumahtangga petani tembakau di lereng Gunung Sumbing (studi kasus di Desa Wonotirto dan Campursari Kecamatan Bulu Kabupaten Temanggung) [tesis]. Bogor (ID): Institut Pertanian Bogor

Wijiadi I. 2007. Analisis ekonomi, ekologi, dan sosial sistem pengelolaan hutan rakyat (kasus di Desa Sambirejo Kecamatan Prambanan Kabupaten Sleman Propinsi DI Yogyakarta) [skripsi]. Bogor (ID): Institut Pertanian Bogor

Wulan KM. 2014. Dampak krisis ekologi terhadap strategi nafkah rumahtangga petani di Desa Ciganjeng, Kecamatan Padaherang, Kabupaten Pangandaran [skripsi]. Bogor (ID): Institut Pertanian Bogor 
Yuliandani R. 2011. Analisis struktur nafkah dan peghidupan rumahtangga pekerja batik tulis tradisional (studi sosio-ekonomi dua tipe industri batik di Kota Pekalongan Provinsi Jawa Tengah) [skripsi]. Bogor (ID): Institut Pertanian Bogor

Yumi. 2011. Model pengembangan pembelajaran petani dalam pengelolaan hutan rakyat lestari: Kasus di Kabupaten Gunung Kidul, Provinsi Daerah Istimewa Yogyakarta dan Kabupaten Wonogiri, Provinsi Jawa Tengah. [disertasi]. Bogor (ID): Institut Pertanian Bogor 